\title{
Correction to: Generation and characterization of tissue-type plasminogen activator transgenic rats
}

\author{
Yusuke Ito ${ }^{1} \cdot$ Kengo Noguchi $^{2} \cdot$ Yoshiyuki Morishima $^{3} \cdot$ Kyoji Yamaguchi $^{1}$
}

Published online: 16 December 2017

c The Author(s) 2017. This article is an open access publication

\section{Correction to: Journal of Thrombosis and Thrombolysis https://doi.org/10.1007/s11239-017-1582-1}

In the original publication of the article, the sentence in "Result" section have been incorrectly published as: "Three lines of tPA Tg rats were generated and analyzed by Southern blotting to confirm the presence of the transgene in genomic DNA. When rat DNA was digested with EcoRI and hybridized to the tPA probe described in "Materials and methods", a $1.0 \mathrm{~kb}$ band was detected (Fig. 1a, b). One founder line was selected because of its high copy number (about ten copies) of tPA gene and itansgene) and $4.4 \mathrm{~kb}$ (endogenous gene) reding appearance, body weight, hematology, and systematization."

The corrected sentence should read as: "Three lines of tPA Tg rats were generated and analyzed by Southern blotting to confirm the presence of the transgene in genomic
DNA. When rat DNA was digested with EcoRI and hybridized to the tPA probe described in "Materials and methods", a $1.0 \mathrm{~kb}$ band was detected (Fig. 1a, b). One founder line was selected because of its high copy number (about ten copies) of tPA gene and its lack of detectable abnormal findings, including appearance, body weight, hematology, and systematization."

The original article has been corrected.

Open Access This article is distributed under the terms of the Creative Commons Attribution 4.0 International License (http://creativecommons.org/licenses/by/4.0/), which permits unrestricted use, distribution, and reproduction in any medium, provided you give appropriate credit to the original author(s) and the source, provide a link to the Creative Commons license, and indicate if changes were made.

The original article can be found online at https://doi.org/10.1007/ s11239-017-1582-1.

Yusuke Ito

ito.yusuke.jj@daiichisankyo.co.jp

1 Rare Disease \& LCM Laboratories, Daiichi Sankyo Co., Ltd., 1-2-58 Hiromachi, Shinagawa-ku, Tokyo 140-8710, Japan

2 Pharmacovigilance Department, Daiichi Sankyo Co., Ltd., Tokyo, Japan

3 Medical Science Department, Daiichi Sankyo Co., Ltd., Tokyo, Japan 